\title{
TNF- $\alpha$ is involved in activating DNA fragmentation in skeletal muscle
}

\author{
N Carbó', S Busquets', M van Royen', B Alvarez', FJ López-Soriano' and JM Argilés*,I \\ 'Cancer Research Group, Departament de Bioquímica i Biologia Molecular, Facultat de Biologia, Universitat de Barcelona, Diagonal 645, 08028-Barcelona, \\ Spain
}

Intraperitoneal administration of $100 \mu \mathrm{g} \mathrm{kg}-1$ (body weight) of tumour necrosis factor- $\alpha$ to rats for 8 consecutive days resulted in a significant decrease in protein content, which was concomitant with a reduction in DNA content. Interestingly, the protein/DNA ratio was unchanged in the skeletal muscle of the tumour necrosis factor- $\alpha$-treated animals as compared with the non-treated controls. Analysis of muscle DNA fragmentation clearly showed enhanced laddering in the skeletal muscle of tumour necrosis factor- $\alpha$-treated animals, suggesting an apoptotic phenomenon. In a different set of experiments, mice bearing a cachexia-inducing tumour (the Lewis lung carcinoma) showed an increase in muscle DNA fragmentation (9.8fold) as compared with their non-tumour-bearing control counterparts as previously described. When gene-deficient mice for tumour necrosis factor- $\alpha$ receptor protein I were inoculated with Lewis lung carcinoma, they were also affected by DNA fragmentation; however the increase was only 2 .I-fold. These results suggest that tumour necrosis factor- $\alpha$ partly mediates DNA fragmentation during experimental cancer-associated cachexia.

British Journal of Cancer (2002) 86, 1012-1016. DOI: 10.1038/sj/bjc/6600167 www.bjcancer.com

(c) 2002 Cancer Research UK

Keywords: DNA fragmentation; skeletal muscle; TNF- $\alpha$; cancer cachexia; apoptosis

Tumour necrosis factor- $\alpha$ (TNF) is a cytokine synthetised and released by blood monocytes and tissue macrophages in response to invasive stimuli, which exerts diverse metabolic effects (see Evans et al, 1989; Argilés et al, 1997 for a review). Although a large body of evidence suggests that this cytokine participates in the protein wasting and loss of nitrogen associated with cachectic situations (Argilés et al, 1997; Argilés and López-Soriano, 1999), the mechanisms underlying such actions still remain obscure. Both in man and mouse, TNF binds as homotrimer to two kinds of receptors, TNFR1 (p55) and TNFR2 (p75) (Hohman et al, 1989); in addition, lymphotoxin- $\alpha$ (LT $\alpha$ or TNF- $\beta$ ) also binds to the same receptors. The pleiotropic functions of TNF can be partially explained by the presence of its receptors in almost all types of nucleated cells. The expression of the genes encoding the two receptors is differentially regulated in different cells. TNFR1 is expressed constitutively and plays a central role in many biological processes, whereas less is known about TNFR2 expression (see Vandenabeele et al, 1995 for a review).

Cancer cachexia is perhaps the most common manifestation of advanced malignant disease. Cachexia occurs in the majority of cancer patients before death, and is responsible for the death of $22 \%$ of these patients (Warren, 1932), although lower percentages have been considered in more recent publications (Dworzak et al, 1998). The abnormalities associated with cancer cachexia include anorexia, weight loss, muscle loss and atrophy, anaemia and alterations in metabolism (see Argilés et al, 1997, for review). The degree of cachexia is inversely correlated with the survival time of the patient and it always implies a poor prognosis (Harvey et al, 1979; Nixon et

*Correspondence: Dr JM Argilés; E-mail: argiles@porthos.bio.ub.es Received 7 September 200I; revised 7 December 2001; accepted 7 January 2002 $a l$, 1980; De Wys, 1985). Perhaps asthenia is one of the most relevant characteristics of cachexia, reflecting the extensive muscle waste that takes place in the cachectic cancer patient (Argilés et al, 1992), and is also characterised by a general weakness as well as physical and mental fatigue (Adams and Victor, 1981). Actually, body protein depletion is one of the main trends of cachexia and it involves not only skeletal muscle but it also affects cardiac proteins, resulting in alterations in heart performance (Drott et al, 1986).

Apoptosis, the programmed type of cell death, is an important physiological process in the development and homeostasis of multicellular organisms. Apoptotic cell death is characterised by a common pattern of morphological alterations such as chromatin condensation, membrane blebbing, DNA fragmentation and cell shrinkage (Huppertz et al, 1999). In cardiac muscle, apoptosis has been recognised as a component of many common pathologies including chronic heart failure, cardiac sudden death, viral myocarditis and ischaemia (Tanaka et al, 1994; Itoh et al, 1996; Kajstura et al, 1996). Moreover, during chronic heart failure, rat skeletal muscle atrophy has been related to apoptosis (Dalla Libera et al, 1999). Indeed, apoptosis has already been described associated with skeletal muscle atrophy (Allen et al, 1997; Tews and Goebel, 1997; Tews et al, 1997) and other diseases (see Sandri and Carraro, 1999, for review).

During cancer cachexia, the activation of the ubiquitin-dependent proteolytic pathway seems to be responsible for the muscle protein mobilisation (Argilés and López-Soriano, 1996). Recently, a link between the apoptosome and the proteasome pathway has been described (Dimmeler et al, 1999). In addition, we have demonstrated that during experimental cancer cachexia, DNA fragmentation is increased in skeletal muscle (Van Royen et al, 2000). Therefore, it was the aim of the present investigation to examine if cytokines, TNF in particular, synthetised during the evolution of the tumour-induced cachectic process, were involved in the changes in skeletal muscle DNA content and integrity. 


\section{MATERIALS AND METHODS}

\section{Animals, tumour inoculation and TNF treatment}

Male C57BL/6 mice (Criffa, Barcelona, Spain) weighing about $25 \mathrm{~g}$ were used. Mice were divided into two groups, namely controls and tumour hosts. The latter received an intramuscular (left thigh) inoculum of $5 \times 10^{5}$ Lewis lung carcinoma cells obtained from exponential tumours. The development of a nodule at the side of the injection, growing in size up to almost $20 \%$ of the animal weight in 2 weeks, was considered as an index of effectiveness of the inoculation. Nearly $100 \%$ of the injected animals developed hind-leg tumours, and all of them were affected by lung metastasis from day 7 onwards. On day 15 after tumour transplantation, animals were weighed and anaesthetised with ketamine/xylacine (Imalgene and Rompun respectively).

Concerning TNFRI-deficient mice, homozygous mice for a disrupted TnfrI allele $\left(\operatorname{Tnfr} \mathrm{I}^{\circ}\right)$ were used. The gene targeting vector consisted of a genomic mouse DNA fragment (Rothe et al, 1993), in which exons 2 and 3 and part of exon 4 of the TnfrI gene were replaced by a neo cassette. This deletion disrupts the gene and removes the coding information for the cysteine-rich domains I and II of the receptor, which have been shown to be essential for ligand binding (Banner et al, 1993). Germ-line transmitters of the mutated TnfrI allele were crossed with C57BL/6 mice and the resulting heterozygous mice interbred to yield homozygous mutant offspring. The F1 generation displayed the expected mendelian $1: 2: 1$ of wild-type $(+/+)$, heterozygous $(0 /+)$ and homozygous $(0 / 0)$ mutant mice, indicating that $\operatorname{TnfrI}$ expression is not required for normal embryonic development.

In the experiments involving chronic TNF treatment, female Wistar rats (Interfauna Iberica) weighing 100-150 g were used. TNF was given intraperitoneally for 8 days at a dose of $100 \mu \mathrm{g} \mathrm{kg}^{-1}$ per day (two administrations at 08:00 and 20:00 h). Control animals received $0.5 \mathrm{ml}$ of vehicle (physiological saline). Human recombinant-derived TNF- $\alpha$ (specific activity $8.1 \times 10^{6} \mathrm{u} \mathrm{mg}^{-1}$ protein, purity $>99 \%$ containing less than $0.137 \mathrm{ng} \mathrm{mg}^{-1}$ endotoxin) was generously given by BASF/Knoll AG (Ludwigshafen, Germany).

All animals were maintained on a regular light-dark cycle (light on from 08:00 to 20:00 h) and had free access to food and water. The diet (BK Universal GJ/SL, Sant Vicenç del Horts, Barcelona, Spain) consisted of $45.5-48.5 \%$ carbohydrate (3.5\% absorbible glucose, $43-45 \%$ starch), $18.5 \%$ protein and $3.1 \%$ fat (the residue was non-digestible material).

All animal experiments have been carried out with ethical committee approval. The ethical guidelines that were followed meet the standards required by the UKCCCR guidelines (Workman et al, 1998).

\section{Biochemicals}

They were all reagent grade and obtained either from Roche (Barcelona, Spain) or from Sigma Chemical Co. (St Louis, MO, USA).

\section{DNA and protein content}

Samples of skeletal muscles were homogenised in an ammonium hydroxide/Triton X-100 extraction buffer (supplemented with protease inhibitors) and used for the determination of both protein (Bradford, 1976) and DNA (Downs and Wilfinger, 1983) content.

\section{DNA fragmentation assay}

Gastrocnemius muscles were homogenised and incubated at $48^{\circ} \mathrm{C}$ overnight in Kauffman buffer $(0.5 \mathrm{~m}$ TRIS, $2 \mathrm{~mm}$ EDTA, $10 \mathrm{~mm}$ $\mathrm{NaCl}, 1 \% \mathrm{SDS}$ ) in the presence of $200 \mu \mathrm{g} \mathrm{ml}^{-1}$ of Proteinase $\mathrm{K}$, and DNA was extracted with phenol/chloroform. After ethanol precipitation, the pellets were resuspended and the DNA integrity was checked in a $2 \%$ agarose gel electrophoresis and ethidium bromide staining. The percentage of DNA fragmentation was quantified by scanning densitometry. Liver from 8 -h anti-Fas antibodytreated mice (Ogasawara et al, 1993) was used as a positive control of DNA fragmentation.

\section{Plasma TNF levels}

Circulating TNF was evaluated by a murine immunoassay (Genzyme, Cambridge, MA, USA).

\section{Statistical analysis}

Statistical analysis of the data was performed by means of the Student's $t$-test.

\section{RESULTS}

As can be seen in Table 1, chronic administration of TNF to rats for 8 consecutive days results in a decrease $(21 \%)$ in skeletal muscle protein content (soleus). The cytokine also induces a similar decrease in muscle DNA content although the results do not reach statistical significance. Interestingly, the protein/DNA ratio is unchanged as a result of TNF treatment. At this point, it seemed that DNA was probably being degraded at a faster rate as a consequence of TNF treatment. As can be seen in Figure 1, DNA fragmentation is clearly induced by the cytokine; indeed it caused an increase of 4.6-fold over the basal fragmentation observed in

Table I Effect of chronic TNF treatment on protein and DNA content in rat soleus muscles

\begin{tabular}{lccc}
\hline $\begin{array}{l}\text { Experimental } \\
\text { group }\end{array}$ & $\begin{array}{c}\text { DNA } \\
\mathbf{m g}(\mathbf{1 0 0} \mathbf{g} \text { ibw })^{-\mathbf{1}}\end{array}$ & $\begin{array}{c}\text { Protein } \\
\mathbf{m g}(\mathbf{1 0 0} \mathbf{g} \text { ibw })^{-1}\end{array}$ & $\begin{array}{c}\text { Protein/ } \\
\text { DNA }\end{array}$ \\
\hline Control & $0.341 \pm 0.029$ & $108.0 \pm 6.7$ & $317 \pm 20$ \\
TNF treatment & $0.268 \pm 0.047$ & $85.0 \pm 4.1 *$ & $317 \pm 15$ \\
\hline
\end{tabular}

The results are mean values \pm s.e.m. for five animals in each group. Statistical significance of the differences (Student's $t$-test): ${ }^{*} P<0.05$; ibw: initial body weight.

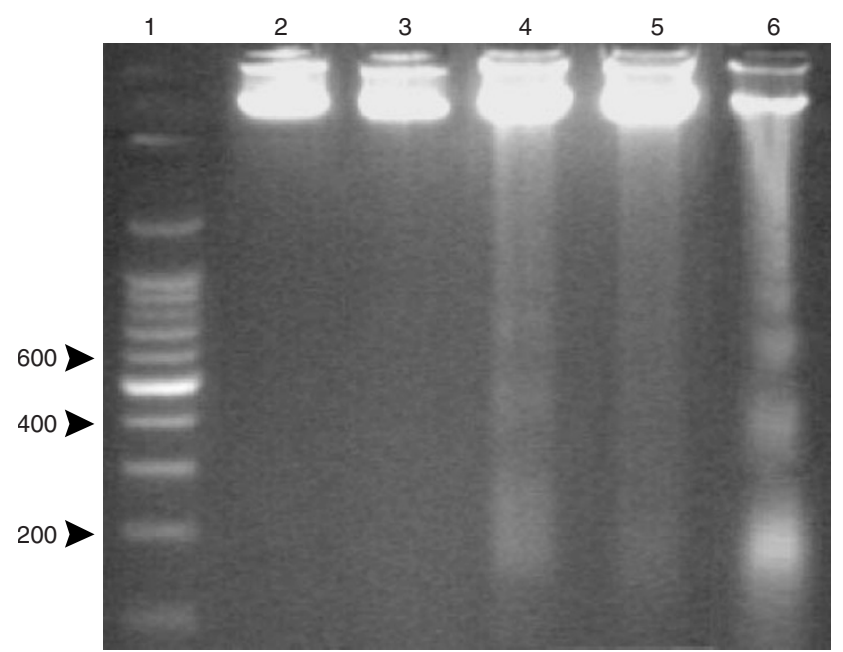

Figure I DNA laddering in rats chronically treated with hrTNF- $\alpha$ (I00 $\mu \mathrm{g} \mathrm{kg}^{-1}$ body weight/day). Lane I: DNA molecular weight marker; lanes 2-5: $40 \mu \mathrm{g}$ of gastrocnemius muscle DNA from control (lanes 2 and 3) and TNF-treated (lanes 4 and 5) rats respectively; lane 6: $20 \mu \mathrm{g}$ of liver DNA from anti-Fas-treated mice (positive control) The percentage of DNA fragmentation was quantified by scanning densitometry. 
the control animals. These data agree with our previous report (Van Royen et al, 2000) demonstrating that during experimental cancer cachexia, DNA fragmentation was an important event in skeletal muscle. For this reason, we decided to investigate if TNF was involved in this apoptotic event, since tumour-bearing animals generally show high circulating levels of the cytokine (Costelli et al, 1993). Bearing all this in mind, in the following experiments we used gene-deficient mice for TNFRI protein (TNFRI KO). As can be seen in Figure 2, tumour growth induced an important decrease in gastrocnemius weight $(26 \%)$ in wild-type animals. In the genedeficient mice, however, tumour burden only caused a $13 \%$ decrease in gastrocnemius weight (Figure 2). Interestingly, control non-tumour-bearing gene-deficient mice have a significantly smaller muscle mass $(21 \%)$ as compared with the control wild-type mice (Figure 2). Similarly, gastrocnemius total protein content was clearly decreased $(29 \%)$ by tumour burden in wild-type mice as well as in the TNFRI KO mice (18\%) (Table 2). The DNA content was also decreased as a result of tumour growth in the wild-type (39\%) and in the TNFRI KO mice (30\%) (Table 2). Interestingly, the protein/DNA ratio was unchanged in the wildtype mice as a result of tumour burden whereas in the gene-deficient mice tumour growth resulted in a significant increase in this ratio (Table 2)

Figure 3 shows the result of the DNA fragmentation analysis. The Lewis lung carcinoma induced a marked increase in DNA fragmentation in wild-type mice (9.8-fold). The tumour also induced

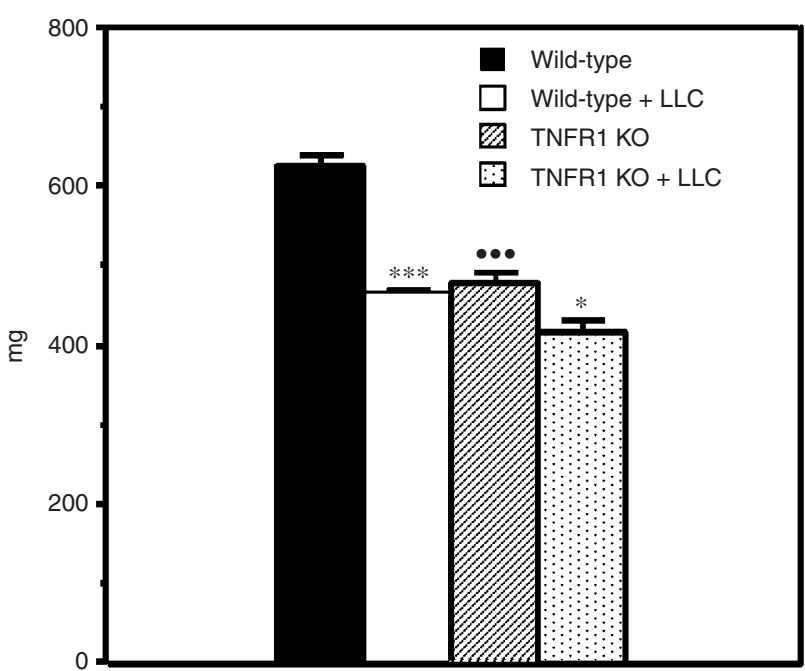

Figure 2 Effects of tumour growth on gastrocnemius weight in tumourbearing mice. Results are $\mathrm{mg}\left(100 \mathrm{~g} \mathrm{ibw}^{-1}\right)$ of initial body weight. Statistical significance of the results: $* P<0,05$; $* * * *<0.00$ I (vs non-tumour); $\cdots p<0.00$ I (vs wild-type) $n=5$ for wild-type and $K O, n=6$ for tumourbearing mice. LLC: Lewis lung carcinoma.

Table 2 Protein and DNA content in mice gastrocnemius muscles

\begin{tabular}{|c|c|c|c|}
\hline $\begin{array}{l}\text { Experimental } \\
\text { group }\end{array}$ & $\begin{array}{c}\text { DNA } \\
\mathrm{mg}(100 \mathrm{~g} \mathrm{ibw})^{-1}\end{array}$ & $\begin{array}{c}\text { Protein } \\
\mathrm{mg}(100 \mathrm{~g} \text { ibw })^{-1}\end{array}$ & $\begin{array}{l}\text { Protein/ } \\
\text { DNA }\end{array}$ \\
\hline $\begin{array}{l}\text { Wild-type } \\
\text { Wild-type+LLC }\end{array}$ & $\begin{array}{l}0.578 \pm 0.052 \\
0.350 \pm 0.011 * * *\end{array}$ & $\begin{array}{l}13.99 \pm 7.0 \\
99.2 \pm 1.3 * * * * 6\end{array}$ & $\begin{array}{l}259 \pm 10 \\
286 \pm 12\end{array}$ \\
\hline $\begin{array}{l}\text { TNFRI KO } \\
\text { TNFI KO+LLC }\end{array}$ & $\begin{array}{l}0.588 \pm 0.031 \\
0.411 \pm 0.017 \# \#\end{array}$ & $\begin{array}{l}112.0 \pm 3.5 * \\
92.2 \pm 3.3 \# \#\end{array}$ & $\begin{array}{l}187 \pm 6 * * * \\
229 \pm 8 \# \#\end{array}$ \\
\hline
\end{tabular}

The results are mean values \pm s.e.m. for four animals in each group. Statistical significance of the differences (Student's $t$-test): $* P<0.05$, ** $P<0.01$, **** $P<0.001$ (vs wild-type); \#\#P<0.0I (vs TNFRI KO). LLC: Lewis lung carcinoma; ibw: initial body weight. an increase in DNA fragmentation in the gene-deficient mice but this was much more modest (2.1-fold). Interestingly, control gene knockout mice have a higher rate of DNA fragmentation (3.9-fold) than that observed in the control wild-type mice (Figure 3). The circulating concentrations of TNF are shown in Table 3. It can be seen that tumour growth results in an increase in circulating cytokine both in wild-type (91\%) and gene-deficient (178\%) animals.

\section{DISCUSSION}

DNA fragmentation is a common feature of apoptotic cell death and we have previously suggested that the muscle wasting that accompanies cancer cachexia could be linked to an apoptotic phenomenon by which muscle cells lose not only protein but also DNA (Van Royen et al, 2000). Apoptosis has already been described in human (Tews and Goebel, 1997; Tews et al, 1997) and rat (Dalla Libera et al, 1999) atrophic muscle as well as in insect muscle (Schwartz et al, 1993). In patients with malignant tumours, anorexia, weight loss, emaciation and progressive alterations of vital functions are common features associated with cancer cachexia (De Wys, 1985). Although in some cases anorexia, gastrointestinal obstruction or malabsorption are responsible for the weight loss of cachectic patients (Balducci and Hardy, 1985), it cannot be wholely attributed to these causes and therefore it has been postulated to be due to a decrease in the energetic efficiency of the cancer patient. Among the factors involved in decreasing the energetic efficiency, skeletal muscle protein turnover seems to have a very significant role as we have previously shown (see Argilés et al, 1997, for review). In addition, apoptosis also seems to be present in cachectic muscle in different experimental tumour models (Van Royen et al, 2000). The basic aim of the

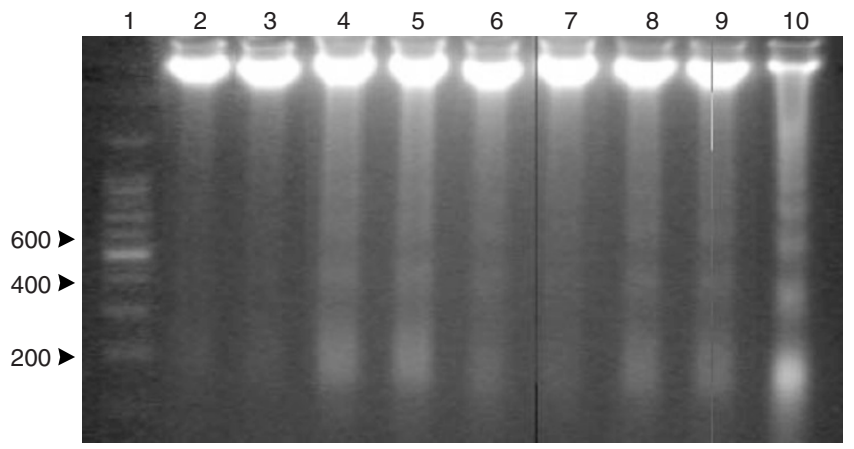

Figure 3 DNA laddering in mice bearing the Lewis lung carcinoma. Lane I: DNA molecular weight marker; lanes 2-5: $35 \mu$ g of gastrocnemius muscle DNA from wild-type control (lanes 2 and 3 ) and tumour-bearing (lanes 4 and 5) respectively; lanes 6-9: $35 \mu$ of gastrocnemius muscle DNA from TNFRI KO mice, control (lanes 6 and 7) and tumour-bearing (lanes 8 and 9) respectively; lane 10: $20 \mu \mathrm{g}$ of liver DNA from anti-Fas-treated mice (positive control) The percentage of DNA fragmentation was quantified by scanning densitometry.

Table 3 Plasma TNF levels in tumour-bearing mice

\begin{tabular}{lc}
\hline Experimental group & TNF $\left(\mathbf{p g} \mathbf{~ m l}^{-\mathbf{1}}\right)$ \\
\hline Wild-type & $22 \pm 7$ \\
Wild-type+LLC & $42 \pm 2 *$ \\
TNFRI KO & $18 \pm 3$ \\
TNFRI KO+LLC & $50 \pm 7 * *$
\end{tabular}

TNF was determined by ELISA. The results are mean values + s.e.m. for five animals in each group. Statistical significance of the differences (Student's $t$-test): $* P<0.05$, $* * P<0.01$ (vs wild-type) 
present investigation was to see if the changes that occur in DNA in skeletal muscle during experimental cancer cachexia are linked to TNF. To test this hypothesis we have used two different experimental approximations: chronic TNF administration to healthy rats and experimental cancer cachexia (induced by the Lewis lung carcinoma in mice) in gene-deficient mice for TNFRI.

Different mediators have been suggested to account for cancerinduced cachexia, but basically the presence of both tumoural and humoural (mainly cytokines, TNF in particular) compounds is associated with depletion of fat stores as well as of muscular tissues (Argilés and López-Soriano, 1999). In fact, the balance between pro-inflammatory cytokines, their soluble receptors and the antiinflammatory cytokines plays a key role in the development of the cachectic syndrome (Argilés and López-Soriano, 1998). Our research group has demonstrated that TNF is involved in the activation of the ubiquitin-dependent proteolysis that takes place during tumour growth (García-Martínez et al, 1994; Llovera et al, 1996, 1998). We clearly show here that TNF is also involved in triggering DNA fragmentation in muscle during cancer cachexia, mainly through the TNFRI. Indeed, chronic administration of recombinant human TNF, which can only bind rat TNFRI, clearly induces DNA fragmentation, and the use of a tumour model (where the levels of circulating TNF are highly increased) confirm this fact.

Indeed, the Lewis lung carcinoma is a cachectic tumour that induces an important decrease in body weight without significant changes in food intake, at least in the two first weeks of tumour growth (Llovera et al, 1998). Because TNFRI is absent from the cells of these animals, the data obtained here suggest that TNF can be involved in the muscle apoptotic mechanisms triggered by tumour growth through its binding with the TNFRI. However, TNFRI is not the sole receptor responsible for transduction of the death signal, even though it is the most important one. Under certain circumstances, TNFRII also either enhances the TNFRI death signal or, indeed, mediates death independently (Declercq et al, 1998; Haridas et al, 1998; Weiss et al, 1998). The mechanism

\section{REFERENCES}

Adams R, Victor M (1981) Asthenia. In Principles of Neurology Adams R, Victor M, (eds) pp 341-345 New York: McGraw-Hill

Allen DL, Linderman JK, Roy RR, Bigbee AJ, Grindeland RE, Mukku V, Edgerton VR (1997) Apoptosis: a mechanism contributing to remodeling of skeletal muscle in response to hindlimb unweighting. Am J Physiol 273: C579-C587

Argilés JM, García-Martínez C, Llovera M, López-Soriano FJ (1992) The role of cytokines in muscle wasting: its relation with cancer cachexia. Med Res Rev 12: 637-652

Argilés JM, López-Soriano FJ (1996) The ubiquitin-dependent proteolytic pathway in skeletal muscle: its role in pathological states. Trends Pharmacol Sci 17: $223-226$

Argilés JM, Alvarez B, López-Soriano FJ (1997) The metabolic basis of cancer cachexia. Med Res Rev 17: 477-498

Argilés JM, López-Soriano FJ (1998) Catabolic proinflammatory cytokines. Curr Opin Clin Nutr Metab Care 1: 241-251

Argilés JM, López-Soriano FJ (1999) The role of cytokines in cancer cachexia. Med Res Rev 19: $223-248$

Balducci L, Hardy C (1985) Cancer and malnutrition: a critical interaction. A review. Am I Hematol 18: $911-1003$

Banner DW, D'Arcy A, Janes W, Gentz R, Schoenfeld HJ, Broger C, Loetscher H, Lesslauer W (1993) Crystal structure of the soluble human $55 \mathrm{kd} \mathrm{TNF}$ receptor-human TNF beta complex: implications for TNF receptor activation. Cell 73: $431-445$

Bradford MM (1976) A rapid and sensitive method for the quantification of microgram quantities of protein utilizing the principle protein-dye binding. Anal Biochem 72: $248-254$

Costelli P, Carbó N, Tessitore L, Bagby GJ, López-Soriano FJ, Argilés JM, Baccino FM (1993) Tumour necrosis factor- $\alpha$ mediates changes in tissue protein turnover in a rat cachexia model. J Clin Invest 92: 2783-2789 of the TNFRII death signal has not been characterised. The results clearly show that in the gene-deficient mice apoptosis is not induced by tumour growth to the same extent as in the wild-type animals. In fact, TNF has been shown to trigger apoptosis in many cell types (Obeid et al, 1993; Ohta et al, 1994; Sidoti-de-Fraisse et al, 1998) including cardiac muscle (Krown et al, 1996). In addition, a possible link between TNF and apoptosis has already been reported in 'fast' skeletal muscles in chronic heart failure (Dalla Libera et al, 1999). Interestingly high circulating levels of TNF are detectable in both rat (Costelli et al, 1993) and mouse (Llovera et al, 1998) tumour models used in this study.

Furthermore, TNF-treatment induces Bcl-2 dephosphorylation, targeting this anti-apoptotic protein for degradation by the ubiquitin proteolytic system (Dimmeler et al, 1999). Thus, TNF-induced apoptosis could be mediated by different cellular responses (Liu et al, 1996), which include the activation of TNFRI death domain and, as a consequence, the caspase cascade and amplification of this apoptotic pathway by means of ubiquitin-dependent Bcl-2 degradation. Nevertheless, TNF binding to its receptors also induces cell proliferation and survival signals mediated by Bcl-2 activation of NF- $\kappa \mathrm{B}$ (Liu et al, 1996; Wang et al, 1996). Therefore, cell survival depends on a delicate balance between the different TNF signalling pathways. For this reason, future investigations in our laboratory will concentrate on ascertaining the role of this and other cytokines in the activation of the apoptotic process associated with cancer cachexia in skeletal muscle.

\section{ACKNOWLEDGEMENTS}

Work supported by grants from the Fondo de Investigaciones Sanitarias de la Seguridad Social (00/1116) of the Spanish Health Ministry, and the Dirección General de Investigación Científica y Técnica (PM98-0199) from the Spanish Ministry of Education and Science.
Dalla Libera L, Zennaro R, Sandri M, Ambrosio GB, Vescovo G (1999) Apoptosis and atrophy in rat slow skeletal muscles in chronic heart failure. $A m J$ Physiol 277: C982-C986

De Wys WD (1985) Management of cancer cachexia. Semin Oncol 12: 452 460

Declercq W, Denecker G, Fiers W, Vandenabeele P (1998) Cooperation of both TNF receptors in inducing apoptosis: involvement of the TNF receptor-associated factor binding domain of the TNF receptor 75. J Immunol 161: $390-399$

Dimmeler S, Breitschopf K, Haendeler J, Zeiher AM (1999) Dephosphorylation targets Bcl-2 for ubiquitin-dependent degradation: a link between the apoptosome and the proteasome pathway. J Exp Med 189: 1815-1822

Downs TR, Wilfinger WW (1983) Fluorometric quantification of DNA in cells and tissue. Anal Biochem 131: $538-547$

Drott C, Ekman L, Holm S, Waldenstrom A, Lundholm K (1986) Effects of tumor-load and malnutrition on myocardial function in the isolated working rat heart. J Mol Cell Cardiol 18: 1165-1176

Dworzak F, Ferrari P, Gavazzi C, Maiorana C, Bozzetti F (1998) Effects of cachexia due to cancer on whole body and skeletal muscle protein turnover. Cancer 82: $42-48$

Evans RD, Argilés JM, Williamson DH (1989) Metabolic effects of tumour necrosis factor- $\alpha$ (cachectin) and interleukin-1. Clin Sci 77: 357-364

García-Martínez C, Llovera M, Agell N, López-Soriano FJ, Argilés JM (1994) Ubiquitin gene expression in skeletal muscle is increased by tumour necrosis factor- $\alpha$. Biochem Biophys Res Commun 201: 682-686

Haridas V, Darnay BG, Natarajan K, Heller R, Aggarwal BB (1998) Overexpression of the p80 TNF receptor leads to TNF-dependent apoptosis, nuclear factor-kappa B activation, and c-Jun kinase activation. J Immunol 160: $3152-3162$ 
Harvey KB, Bothe A, Blackburn GL (1979) Nutritional assessment and patient outcome during oncological therapy. Cancer 43: 2065-2069

Hohman HP, Remy R, Brockhaus M, van Loon APGM (1989) Two different cell types have different major receptors for human tumor necrosis factor (TNF $\alpha)$. J Biol Chem 264: 14927-14934

Huppertz B, Frank HG, Kaufmann P (1999) The apoptosis cascade: morphological and immunohistochemical methods for its visualization. Anat Embryol 200: 1-18

Itoh G, Jie T, Tamura J, Suzuki M, Suzuki Y, Ikeda M, Nomura M (1996) Apoptosis and human ischemic myocardial damage, including conduction system. Basic Appl Myol 6: 237-240

Kajstura J, Cheng W, Reiss K, Clark WA, Sonnenblick EH, Krajewski S, Reed JC, Olivetti G, Anversa P (1996) Apoptotic and necrotic cell death are independent contributing variables of infarct size in rats. Lab Invest 74 $86-107$

Krown KA, Page MT, Nguyen C, Zechner D, Gutierrez V, Comstock KL Glembotski CC, Quintana PJE, Sabbadin RA (1996) Tumor necrosis factor alpha-induced apoptosis in cardiac myocytes. J Clin Invest 98: 2854-2865

Liu ZG, Hsu H, Goeddel DV, Karin M (1996) Dissection of TNF receptor-1 effector functions: JNK activation is not linked to apoptosis while NF- $\kappa \mathrm{B}$ activation prevents cell death. Cell 87: $565-576$

Llovera M, Carbó N, García-Martínez C, Costelli P, Tessitore L, Baccino FM, Agell N, Bagby GJ, López-Soriano FJ, Argilés JM (1996) Anti-TNF treatment reverts increased muscle ubiquitin gene expression in tumorbearing rats. Biochem Biophys Res Commun 221: 653-655

Llovera M, García-Martínez C, López-Soriano J, Carbó N, Agell N, LópezSoriano FJ, Argilés JM (1998) Role of TNF receptor 1 in protein turnover during cancer cachexia using gene knockout mice. Mol Cell Endocrinol 142: $183-189$

Nixon DW, Heymsfield SB, Kutner MM, Ansley J, Lawson DH (1980) Protein-caloric undernutrition in hospitalized cancer patients. Am J Med 68: $491-497$

Obeid LM, Linardic CM, Karolak LA, Hannun YA (1993) Programmed cell death induced by ceramide. Science 259: 1769-1771

Ogasawara J, Watanabe-Fukunaga R, Adachi M, Matsuzawa A, Kasugai T, Kitamura Y, Itoh N, Suda T, Nakata S (1993) Lethal effect of the antiFas antibody in mice. Nature 364: 806-809

Ohta H, Yalomi Y, Sweeney EA, Hakomori SI, Igarashi Y (1994) A possible role of sphingosinin induction of apoptosis by tumour necrosis factor- $\alpha$ in human neutrophils. FEBS Lett 355: 267-270

Rothe J, Lesslauer W, Lötscher H, Lang Y, Koebel P, Köntgen F, Althage A, Zinkernagel R, Steinmetz M, Bluethmann H (1993) Mice lacking the tumour necrosis factor receptor 1 are resistant to TNF-mediated toxicity but susceptible to infection by Listeria monocytogenes. Nature 364: $798-802$
Sandri M, Carraro U (1999) Apoptosis of skeletal muscles during development and disease. Int J Biochem Cell Biol 31: 1373-1390

Schwartz LM, Jones ME, Kosz L, Kuah K (1993) Selective repression of actin and myosin heavy chain expression during the programmed cell death of insect skeletal muscle. Dev Biol 158: $448-455$

Sidoti-de-Fraisse C, Rincheval V, Risler Y, Mignotte B, Vayssière JL (1998) TNF- $\alpha$ activates at least two apoptotic signaling cascades. Oncogene 17: $1639-1651$

Tanaka M, Ito H, Adachi S, Akimoto H, Hishikawa T, Kasajima T, Marumo F, Hiroe M (1994) Hypoxia induces apoptosis with enhanced expression of fas antigen messenger RNA in cultured neonatal rat cardiomyocites. Circ Res 73: $426-433$

Tews DS, Goebel HH (1997) Apoptosis-related proteins in skeletal muscle fibers of spinal muscular atrophy. J Neuropathol Exp Neurol 56: 150-156

Tews DS, Goebel HH, Meinck HM (1997) DNA fragmentation and apoptosis-related proteins of muscle cells in motor neuron disorders. Acta Neuro Scand 96: $380-386$

Van Royen M, Carbó N, Busquets S, Alvarez B, Quinn LS, López-Soriano FJ Argilés JM (2000) DNA fragmentation occurs in skeletal muscle during tumor growth: a link with cancer cachexia? Biochem Biophys Res Commun 270: $533-537$

Vandenabeele P, Declercq W, Beyaert R, Fiers W (1995) Two tumor necrosis factor receptors: structure and functions. Trends Cell Biol 5: $392-399$

Wang CI, Mayo MW, Baldwin Jr AS (1996) TNF- and cancer therapyinduced apoptosis: potentiation by inhibition of NF- $\kappa$ B. Science 274 $784-787$

Warren S (1932) The immediate cause of death in cancer. Am J Med Sci 184 $610-613$

Weiss T, Grell M, Siemienski K, Muhlenbeck F, Durkop H, Pfizenmaier K, Scheurich P, Wajant H (1998) TNFR80-dependent enhancement of TNFR60-induced cell death is mediated by TNFR-associated factor 2 and is specific for TNFR60. J Immunol 161: 3136-3142

Workman P, Balmain A, Hickman JA, McNally NJ, Rohas AM, Mitchison NA, Pierrepoint CG, Raymond R, Rowlatt C, Stephens TC, Wallace (1998) UKCCCR guidelines for the welfare of animals in experimental neoplasia (second edition). Br J Cancer 77: $1-10$ 